\title{
Multidimensional Analysis of Social Convergence Within the European Union Countries
}

\author{
Agnieszka Głodowska \\ Cracow University of Economics, Cracow, Poland
}

\begin{abstract}
Social convergence is one of the most important objectives for European integration. It is understood as a process of cohesion and assimilation of countries in the area of social development, which is the conditions and standards of living of the citizens of the European countries (EU27). The aim of the article was to investigate whether there is convergence or divergence in the EU27 area, taking into account multidimensional analysis of social convergence. Methodology used in the article was taxonomic and statistical tool. It allowed applying the synthetic approach to the issue. The time taken into consideration was the period of 2000-2013. The article showed that the area of the EU27 is very diversified in terms of social development. It allows indicating five groups of countries similar to each other due to the level of social development, although the differences among the groups are significant. The analysis of convergence led to the conclusion that the process of "catching up" occurred until 2007. Then this process has stopped and even divergence trends are visible due to crisis 2008/2009. The period of 2008-2011 revealed the greatest disparities of development among the EU countries.
\end{abstract}

Keywords: social convergence, income convergence, taxonomic measure of development, the European Union

\section{Introduction}

Creating wealth and improving living conditions of European citizens compound a fundamental and basic aim set at the beginning of the integration process. Its implementation in accordance with the fundamental principles of integration, such as unity, equality, and solidarity is a precondition for deeper integration and the accession of more countries to the EU structures. Achieving this overarching objective of socio-economic development of all members of the Community was only possible through early elimination of disparities in development among member states, both at national and regional levels. The need for sustainable development was first articulated in the founding documents of the Community and its tangible instruments have proved to be of European funds (Treaty of Rome, 1957). Financial support for regions and member states with a lower level of development was passed as part of regional policy and cohesion policy. Importance of the levelling disproportions in development increases from year to year, which is reflected in the size of the allocated funds for this purpose. This means on one hand that this is a key objective in community's activity; on the other hand, it indicates that the problem of uneven development and great socio-economic disparities is still present in the Union. Despite the huge financial and functional commitment of the Union in creating cohesion within

Agnieszka Głodowska, Ph.D. in economics, Department of Foreign Trade, Cracow University of Economics, Cracow, Poland. Correspondence concerning this article should be addressed to Agnieszka Głodowska, Department of Foreign Trade, Cracow University of Economics, Rakowicka 27, 31-510 Cracow, Poland. 
European states, it continues to be an area that is very diversified, moreover, social discontent associated with it is still visible. Therefore, the effectiveness of measures taken in the field of unification of European countries and regions seems to be questionable. However, you cannot question the community acquis, which took place over the years and the progress of countries, which they have achieved in terms of social and economic development after the accession to the European Union. Literature does not provide a clear answer on the convergence of European countries and regions. However, it should be noted that the previous studies of convergence within the Union largely referred to analysing and comparing the economic growth expressed by gross domestic product (GDP) per capita, i.e., income (economic) convergence.

According to the studies of the European Commission, there is a gradual levelling of differences in socio-economic member states and EU regions. This is shown, for instance, in the so-called Cohesion Reports $(2007,2010)$. The presence of economic convergence has been confirmed also by the following authors: Kaitila (2004), Varblane and Vahter (2005), Matkowski and Próchniak (2006). The authors studied the convergence of the so-called "New Member States", that is, those who have joined the EU since 2004, and the so-called "Old Member States", i.e., countries that functioned so far in the EU structures. The results of these studies revealed the prevalence of convergence and the slow catch-up of countries newly admitted being at a lower level of development towards the old EU members. One of the more recent researches on the convergence by Dvorokova (2014) concerned the 28 EU countries and the period of 2001-2012. The aim of the analysis was to confront the model of income convergence, as well as examine the impact of the economic crisis on the convergence process as an exogenous factor. The author confirmed the presence of convergence, which indicated that countries with low GDP per capita in the initial period of analysis were characterized by the highest growth dynamics. These were countries, such as Romania, Bulgaria, Lithuania, and Latvia. Opposite phenomenon occurred in the case of Ireland, the Netherlands, Italy, France, and Belgium. Conclusion from the analysis was that the crisis had a negative impact on economic growth of the member states. However, there were situations that despite these negative trends, certain economies at a lower level were "catching up" with richer countries, for example Slovakia (Dvorokova, 2014).

Despite numerous studies confirming the gradual process of convergence in the area of countries, in the recent times, the divergent trends were highlighted (Alexe, 2012; Glodowska, 2012; Cuestas, Monfort, \& Ordones, 2012). This can refer to countries at different level of development and with different economic structures, as well as in the regional profile. As already mentioned, the previous studies of convergence within the Union largely referred to comparing the economic growth expressed in GDP per capita. This approach is very limited, because such understood convergence does not reflect real changes in the level of life of residents of surveyed state that is a component of many areas of human activity, such as work, health, education, social relationships, etc. the impact on these spheres is a basis of structural policy of the community. As a result, the limits of research to analyse the convergence of GDP, are that one does not obtain reliable information about real changes in the structures of individual states. Moreover, the use of GDP per capita to assess economic development and standard of living has been questioned in many scientific studies (e.g., Stiglitz, Sen, \& Fitoussi, 2009). There is therefore a need for a multidimensional approach to the study of convergence in the Union and thus for providing more reliable information about the real changes taking place in European countries. Therefore, the subject of this article is the analysis of convergence process among member states of the community. The aim of the elaboration is to investigate whether there is a convergence or divergence in the EU area, taking into account multivariate analysis of social convergence. The social convergence is understood 
as a process of convergence and assimilation of countries in the area of social development, which is the conditions and standards of living of the citizens of the European countries. Therefore, the social convergence is recognized as a multidimensional category that takes into account the various spheres of activity and human functioning that can be objectively investigated. For this purpose, as a research method, the taxonomic tools have been applied. They allow applying the synthetic approach to the issue. The time taken into consideration in the article is the period of 2000-2013.

\section{Taxonomic Measure of Development as a Tool for Analyzing Convergence}

When analysing the social convergence in the international section, it is not sufficient to use one measure or a set number of variables that can be compared directly. This problem is in fact much more complex and requires an aggregated approach. There is a need to use multiple data describing various spheres of life, having a direct impact on social development, e.g., demography, medical care, labour market, infrastructure, education, etc. A common method used to study the conditions of life, standard of living, and socio-economic development is multidimensional comparative analysis. For this purpose, the taxonomic measure of development (TMD) by Hellwig (1968) has been applied. This method provides the possibility to study particular effects in an aggregated way using a large quantity of diagnostic data simultaneously. Thus, the basis of multidimensional analysis is the selection of appropriate variables, which most adequately reflect the studied phenomenon. This requires, above all, an approach of an expert. One can also use statistical measures for the initial selection of variables, such as coefficient of variation, correlation, and asymmetry. The point is that in the final set of variables, the information is not replicated. After the initial selection limited by availability of data for a relatively large group of countries and a fairly extensive period of time, finally, in order to conduct the analysis of social convergence, the following set of variables has been selected (Table 1):

Table 1

Diagnostic Variables Used to Build a Taxonomic Measure of Development in the EU

\begin{tabular}{|c|c|}
\hline Social sphere & Diagnostic variables \\
\hline \multirow{5}{*}{$\begin{array}{l}\text { Demography and } \\
\text { medical care }\end{array}$} & Infant mortality rate (per 1,000 live births) \\
\hline & Available beds in hospitals (per 100,000 inhabitants) \\
\hline & Available doctors (per 1,000 inhabitants) \\
\hline & Fertility rate \\
\hline & Old dependency ratio (population 65 and over to population 15 to 64 years) \\
\hline \multirow{6}{*}{$\begin{array}{l}\text { Education and } \\
\text { development }\end{array}$} & Population between $25-64$ with tertiary educational attainment-level 5-8 (\% of total) \\
\hline & Early leavers from education and training (\% of total population) \\
\hline & Total R\&D expenditure (as \% GDP) \\
\hline & Participation rate in education and training-people between $24-64$ (\& of total) \\
\hline & Persons employed in science and technology (\% of total population) \\
\hline & Exports of high technology products (as \% of total exports) \\
\hline \multirow{4}{*}{$\begin{array}{l}\text { Employment and } \\
\text { earnings }\end{array}$} & Unemployment rate $(\%)$ \\
\hline & Net earnings-Two-earner married couple, one at $100 \%$, the other at $100 \%$ of AW, with no children (in PPS) \\
\hline & GDP per person employed (in PPS) \\
\hline & Unemployment rate with tertiary education $(\%)$ \\
\hline \multirow{4}{*}{$\begin{array}{l}\text { Incomes and } \\
\text { expenses of the } \\
\text { population }\end{array}$} & Net national disposable income (PPS per capita) \\
\hline & Net saving (PPS per capita) \\
\hline & Final consumption expenditure of households (PPS per capita) \\
\hline & Food consumption expenditure (\% of total) \\
\hline
\end{tabular}


Table 1 continued

\begin{tabular}{|c|c|}
\hline Social sphere & Diagnostic variables \\
\hline \multirow{5}{*}{$\begin{array}{l}\text { Environment, } \\
\text { infrastructure and } \\
\text { communication }\end{array}$} & Passenger cars (per 1,000 inhabitants) \\
\hline & Density of road network (kilometres per $\mathrm{km}^{2}$ of land) \\
\hline & Internet users ( $\%$ of total population) \\
\hline & Mobile phone subscriptions ( per 1,000 inhabitants) \\
\hline & $\mathrm{CO}^{2}$ Emissions from the Consumption and Flaring of Fossil Fuels (kg per capita) \\
\hline \multirow{4}{*}{$\begin{array}{l}\text { Social relation and } \\
\text { security }\end{array}$} & Alcoholic beverages, tobacco and narcotics consumption expenditure ( $\%$ of total) \\
\hline & Crude marriage rate (per 1,000 inhabitants) \\
\hline & Deaths from assaults (per 100,000 inhabitants) \\
\hline & Homicide (per 100,000 inhabitants) \\
\hline \multirow{4}{*}{$\begin{array}{l}\text { Culture and } \\
\text { recreation }\end{array}$} & Annual cinema trips per capita \\
\hline & Recreation and culture expenditure (\% of total) \\
\hline & Books and newspapers expenditure (\% of total) \\
\hline & Restaurant and hotels expenditure ( $\%$ of total) \\
\hline
\end{tabular}

Source: Own work based on the Eurostat, World Bank, Euromonitor Databases.

These variables were grouped, which reflects the core area of human activity, which translates into the standard of living. These groups include variables representing these areas. These are the so-called stimulants or destimulants. The stimulant refers to variables that have a stimulating effect on the level of development of the phenomenon studied and therefore are desirable as their highest values. Destimulants are variables acting to hinder the development of the phenomenon and therefore high values are not desirable.

Variables from Table 1 are the basis for estimating TMD for the EU countries. The first step in this process is the elimination of the different range of variables. It means that variables must get rid of their natural units to become comparable. It is possible due to standardization in accordance with the following formula (Hellwig, 1967):

$$
Z_{i j t}=\frac{X_{i j t}-\bar{X}_{j t}}{S_{j t}}
$$

where,

$$
\begin{gathered}
Z_{i j t}-\text { value of standardized variable } \\
X_{i j t}-\text { value of } j \text { variable of } i \text { country in } t \text { year } \\
\bar{X}_{j t}-\text { arithmetic mean of } j \text { variable in } t \text { year } \\
S_{j t}-\text { standard deviation of } j \text { variable in } t \text { year }
\end{gathered}
$$

Next step in the analysis is to indicate pattern model of development indicator for each variable. Then, it is needed to determine the distance between the observed variable and the pattern model of the development. The distance for standardized variables was estimated according to the following rule (Hellwig, 1967):

where,

$$
\begin{gathered}
Z_{0 j t}=\max \left\{Z_{j t}\right\} \text { for stimulant } \\
Z_{0 j t}=\min \left\{Z_{j t}\right\} \text { for destimulant }
\end{gathered}
$$

$Z_{0 j t}-$ value of $j$ standardised variable of the pattern model

$$
d_{0 i t}=\sqrt{\sum_{j=t}\left(Z_{i j t}-Z_{0 j t}\right)^{2}}
$$


where,

$$
d_{0 i t} \text { - Euclidean distance of } i \text { country from the pattern model }
$$

The last element of the presented method is the determination of a taxonomic development measurement. It means that the selected variables are transferred into one aggregated indicator. TMD is between $0-1$, where values closer to the 1 provide a higher level of development of the country. The final TMD measure was estimated according to the following formula (Hellwig, 1967):

where,

$$
\begin{aligned}
& T M D_{i t}=1-\frac{d_{0 i t}}{d_{0 t}} \\
& d_{0 t}=\bar{d}_{0 i t}+2 S_{d t}
\end{aligned}
$$

$$
\begin{gathered}
T M D_{i t}-\text { taxonomic measure of development for } i \text { country } \\
\bar{d}_{0 i t}-\text { arithmetic mean of Euclidean distance } \\
S_{d t}-\text { standard deviation of Euclidean distance } \\
T M D_{i t} \in[0 ; 1]
\end{gathered}
$$

To analyze and interpret the value of TMD, the box and whisker plot was used. The box and whisker plot is composed of one rectangle and two whiskers. Each side of the box and its whisker has its own interpretation. The sides of the box define the quartiles. The first quartile defines the lower side of the box, and the third quartile is the upper side. The width of the box is not important and does not play any informational role. Bottom side of the box is connected with a straight line with a minimum value of GDP per capita, creating a lower whisker and vice versa. The upper side of the box is combined with the maximum value to form the upper whisker. Inside the box with a square, one marked the position of the median. Box and whisker plot analysis provides information on the distribution of the selected features, in this case, TMD among countries of the EU. Differentiation of the TDM can be determined by comparing the length of the four sections defining the ranges of numerical values for the next $25 \%$ of the respondents. The first section is the lower whisker and bottom side of the box, the second section is the lower side of the box and the median value (square in the box), the third section is the value of the median and the upper side of the box, and the fourth section is the upper side of the box and the top whisker. The longer is the section, the greater is the diversity in the given group of $25 \%$ units and vice versa. The diversity in $50 \%$ of the most common units, centrally situated in the distribution, is determined by the height of the box. The higher it is against the entire plot, the more different between each other in the most typical units, and the smaller the variation of characteristics of $50 \%$ of border units ( $25 \%$ of the highest values of characteristics and $25 \%$ of the minimum values). The asymmetry may be evaluated by the length of whiskers. If the upper whisker is longer than the bottom, the distribution of the feature is characterized by right-sided asymmetry, which means that more of the respondents have lower values of the feature. If lower whisker is longer than the upper, the distribution has a character of left-sided asymmetry. In the case when the length of the whiskers is equal, we are dealing with symmetric distribution (Bielecka, 2011).

\section{Empirical Results of Convergence Analysis Within the European Union Countries Between 2000-2013}

The value of taxonomic measure of social development of the European Union countries resulting from an aggregation of individual diagnostic variables is presented in Table 2. 
Table 2

The Value of TMD for the European Union Countries Between 2000-2013

\begin{tabular}{|c|c|c|c|c|c|c|c|c|c|c|c|c|c|c|}
\hline Country $\backslash$ year & 2000 & 2001 & 2002 & 2003 & 2004 & 2005 & 2006 & 2007 & 2008 & 2009 & 2010 & 2011 & 2012 & 2013 \\
\hline Austria & 0.382 & 0.374 & 0.391 & 0.399 & 0.444 & 0.426 & 0.426 & 0.381 & 0.387 & 0.418 & 0.447 & 0.503 & 0.468 & 0.462 \\
\hline Belgium & 0.387 & 0.372 & 0.376 & 0.370 & 0.387 & 0.366 & 0.354 & 0.323 & 0.320 & 0.351 & 0.372 & 0.389 & 0.368 & 0.356 \\
\hline Bulgaria & 0.020 & 0.005 & 0.009 & 0.019 & 0.037 & 0.057 & 0.063 & 0.041 & 0.057 & 0.072 & 0.067 & 0.087 & 0.062 & 0.075 \\
\hline Cyprus & 0.278 & 0.273 & 0.282 & 0.270 & 0.264 & 0.257 & 0.249 & 0.225 & 0.216 & 0.228 & 0.254 & 0.260 & 0.215 & 0.195 \\
\hline Czech Republic & 0.231 & 0.240 & 0.251 & 0.258 & 0.261 & 0.259 & 0.259 & 0.244 & 0.243 & 0.257 & 0.256 & 0.282 & 0.249 & 0.241 \\
\hline Denmark & 0.432 & 0.421 & 0.440 & 0.437 & 0.448 & 0.442 & 0.440 & 0.403 & 0.406 & 0.426 & 0.432 & 0.475 & 0.439 & 0.424 \\
\hline Estonia & 0.170 & 0.147 & 0.155 & 0.159 & 0.191 & 0.201 & 0.221 & 0.197 & 0.174 & 0.148 & 0.160 & 0.260 & 0.249 & 0.256 \\
\hline Finland & 0.414 & 0.396 & 0.408 & 0.403 & 0.419 & 0.413 & 0.407 & 0.374 & 0.388 & 0.410 & 0.427 & 0.492 & 0.433 & 0.397 \\
\hline France & 0.389 & 0.388 & 0.384 & 0.388 & 0.377 & 0.359 & 0.350 & 0.318 & 0.323 & 0.348 & 0.361 & 0.391 & 0.374 & 0.389 \\
\hline Germany & 0.382 & 0.366 & 0.363 & 0.360 & 0.369 & 0.335 & 0.330 & 0.311 & 0.322 & 0.358 & 0.382 & 0.424 & 0.408 & 0.411 \\
\hline Greece & 0.169 & 0.176 & 0.182 & 0.200 & 0.183 & 0.170 & 0.160 & 0.136 & 0.136 & 0.153 & 0.135 & 0.097 & 0.067 & 0.059 \\
\hline Hungary & 0.196 & 0.203 & 0.215 & 0.226 & 0.220 & 0.200 & 0.193 & 0.157 & 0.153 & 0.167 & 0.166 & 0.183 & 0.165 & 0.156 \\
\hline Ireland & 0.365 & 0.357 & 0.369 & 0.395 & 0.406 & 0.418 & 0.417 & 0.373 & 0.345 & 0.319 & 0.337 & 0.375 & 0.348 & 0.357 \\
\hline Italy & 0.274 & 0.275 & 0.274 & 0.264 & 0.272 & 0.246 & 0.246 & 0.227 & 0.219 & 0.234 & 0.242 & 0.181 & 0.234 & 0.214 \\
\hline Latvia & 0.057 & 0.063 & 0.080 & 0.083 & 0.104 & 0.115 & 0.129 & 0.133 & 0.126 & 0.056 & 0.056 & 0.012 & 0.102 & 0.127 \\
\hline Lithuania & 0.066 & 0.066 & 0.083 & 0.083 & 0.084 & 0.104 & 0.109 & 0.115 & 0.101 & 0.082 & 0.096 & 0.249 & 0.170 & 0.182 \\
\hline Luxembourg & 0.341 & 0.363 & 0.350 & 0.349 & 0.374 & 0.356 & 0.339 & 0.317 & 0.292 & 0.309 & 0.355 & 0.457 & 0.362 & 0.349 \\
\hline Malta & 0.319 & 0.315 & 0.317 & 0.339 & 0.337 & 0.326 & 0.331 & 0.280 & 0.278 & 0.300 & 0.303 & 0.404 & 0.323 & 0.302 \\
\hline Netherlands & 0.451 & 0.433 & 0.443 & 0.453 & 0.452 & 0.436 & 0.448 & 0.412 & 0.410 & 0.431 & 0.443 & 0.471 & 0.450 & 0.430 \\
\hline Poland & 0.129 & 0.117 & 0.108 & 0.101 & 0.097 & 0.082 & 0.085 & 0.100 & 0.112 & 0.161 & 0.180 & 0.205 & 0.189 & 0.183 \\
\hline Portugal & 0.225 & 0.217 & 0.206 & 0.208 & 0.199 & $0 ., 174$ & 0.149 & 0.115 & 0.113 & 0.138 & 0.153 & 0.181 & 0.144 & 0.131 \\
\hline Romania & 0.008 & 0.010 & 0.030 & 0.032 & 0.041 & 0.043 & 0.051 & 0.043 & 0.022 & 0.006 & 0.009 & 0.009 & 0.022 & 0.032 \\
\hline Slovakia & 0.155 & 0.155 & 0.165 & 0.156 & 0.153 & 0.132 & 0.136 & 0.132 & 0.137 & 0.183 & 0.197 & 0.249 & 0.198 & 0.196 \\
\hline Slovenia & 0.248 & 0.254 & 0.256 & 0.251 & 0.265 & 0.239 & 0.253 & 0.224 & 0.228 & 0.244 & 0.249 & 0.282 & 0.255 & 0.242 \\
\hline Spain & 0.257 & 0.262 & 0.257 & 0.271 & 0.266 & 0.276 & 0.258 & 0.225 & 0.172 & 0.169 & 0.188 & 0.189 & 0.164 & 0.157 \\
\hline Sweden & 0.394 & 0.372 & 0.388 & 0.396 & 0.402 & 0.389 & 0.389 & 0.369 & 0.377 & 0.392 & 0.418 & 0.462 & 0.429 & 0.428 \\
\hline United Kingdom & 0.395 & 0.389 & 0.403 & 0.426 & 0.433 & 0.431 & 0.430 & 0.382 & 0.378 & 0.381 & 0.376 & 0.419 & 0.374 & 0.364 \\
\hline
\end{tabular}

Source: Own work based on the Eurostat, World Bank, Euromonitor Databases.

Value of synthetic measure of social development concerning countries of the European Union in the period of 2000-2013 ranged from 0.005 to 0.503 . This indicates a large gap of development in the field of EU member states. The lowest values of synthetic measure are recorded in Romania throughout the analysed period. In the case of the highest values of synthetic measure, one cannot indicate a country that would keep the value at the highest level throughout the analysed period. The leaders, however, include the Netherlands, Austria, and Finland. In case of the most countries, the measure of it has a growing trend, but there are also countries where the value of synthetic measure decreases over subsequent years, which would indicate a worsening of the social situation in the country. A clearer picture of diversification of the EU countries in terms of socio-economic development is available after the grouping of countries. For this purpose a cluster analysis was used. On the basis of the grouping conducted by Ward's method, the classification of EU countries was performed on the basis of social development. Figures 1 and 2 present the classification results for the first and last period of the analysis. 


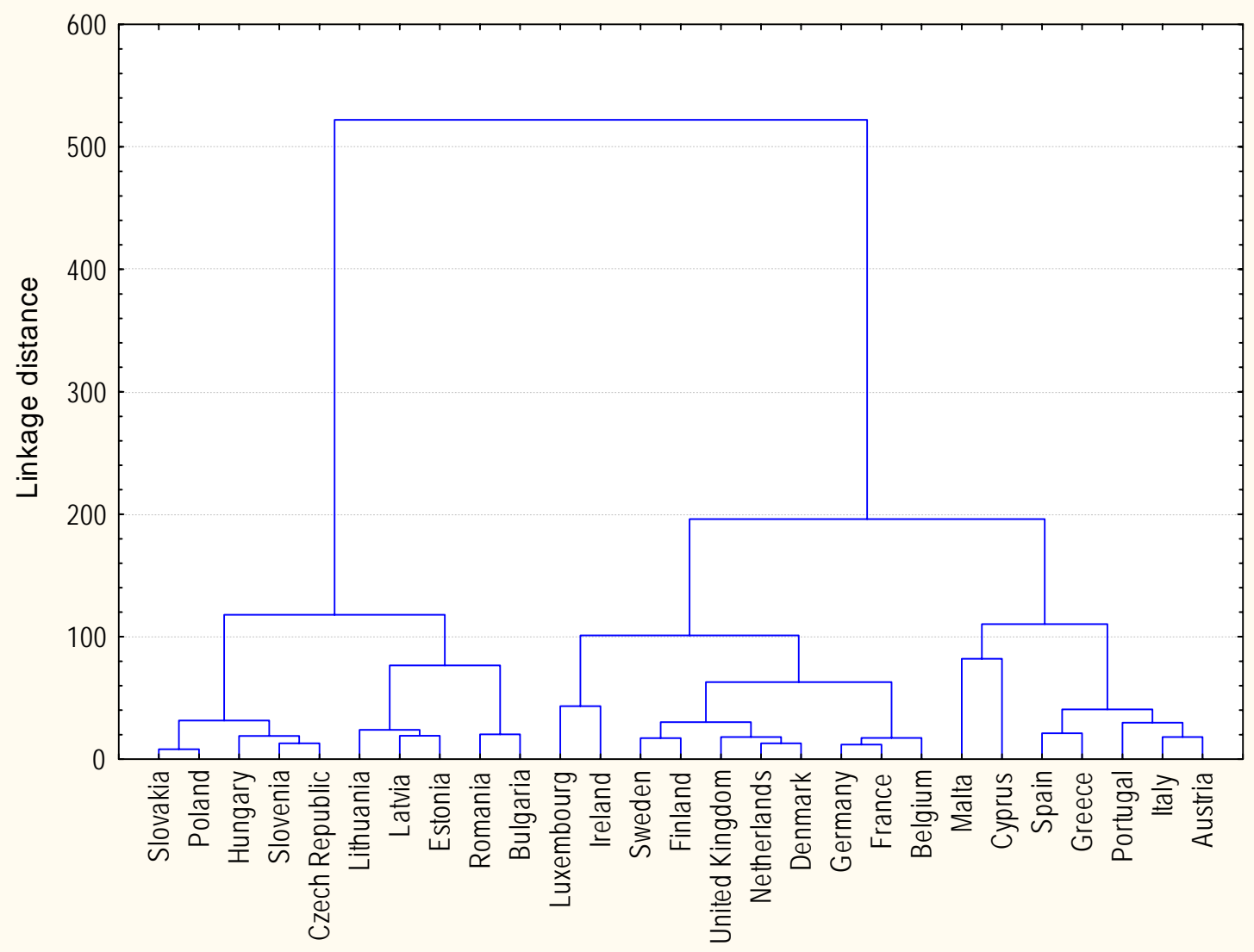

Figure 1. Classification of the EU countries according to TMD in 2000: Ward's method, Euclid's distance. Source:

Own work based on the Eurostat, World Bank, Euromonitor Databases.

On the basis of Figure 1, it can indicate six groups of countries according to social development. These groups are:

Group 1: Slovakia, Poland, Hungary, Slovenia, and Czech Republic;

Group 2: Lithuania, Latvia, Estonia, Romania, and Bulgaria;

Group 3: Luxemburg and Ireland;

Group 4: Sweden, Finland, Great Britain, Netherlands, Denmark, Germany, France, and Belgium;

Group 5: Malta and Cyprus;

Group 6: Spain, Greece, Portugal, Italy, and Austria.

On the basis of Figure 2 (below) it can indicate five groups of countries according to social development. These groups are:

Group 1: Spain, Portugal, Italy, and Greece;

Group 2: Lithuania, Latvia, and Estonia;

Group 3: Malta;

Group 4: Slovakia, Poland, Slovenia, Hungary, Czech Republic, Cyprus, Romania, and Bulgaria;

Group 5: Luxemburg, Ireland, United Kingdom, Netherlands, France, Belgium, Finland, Sweden, Denmark, Germany, and Austria. 


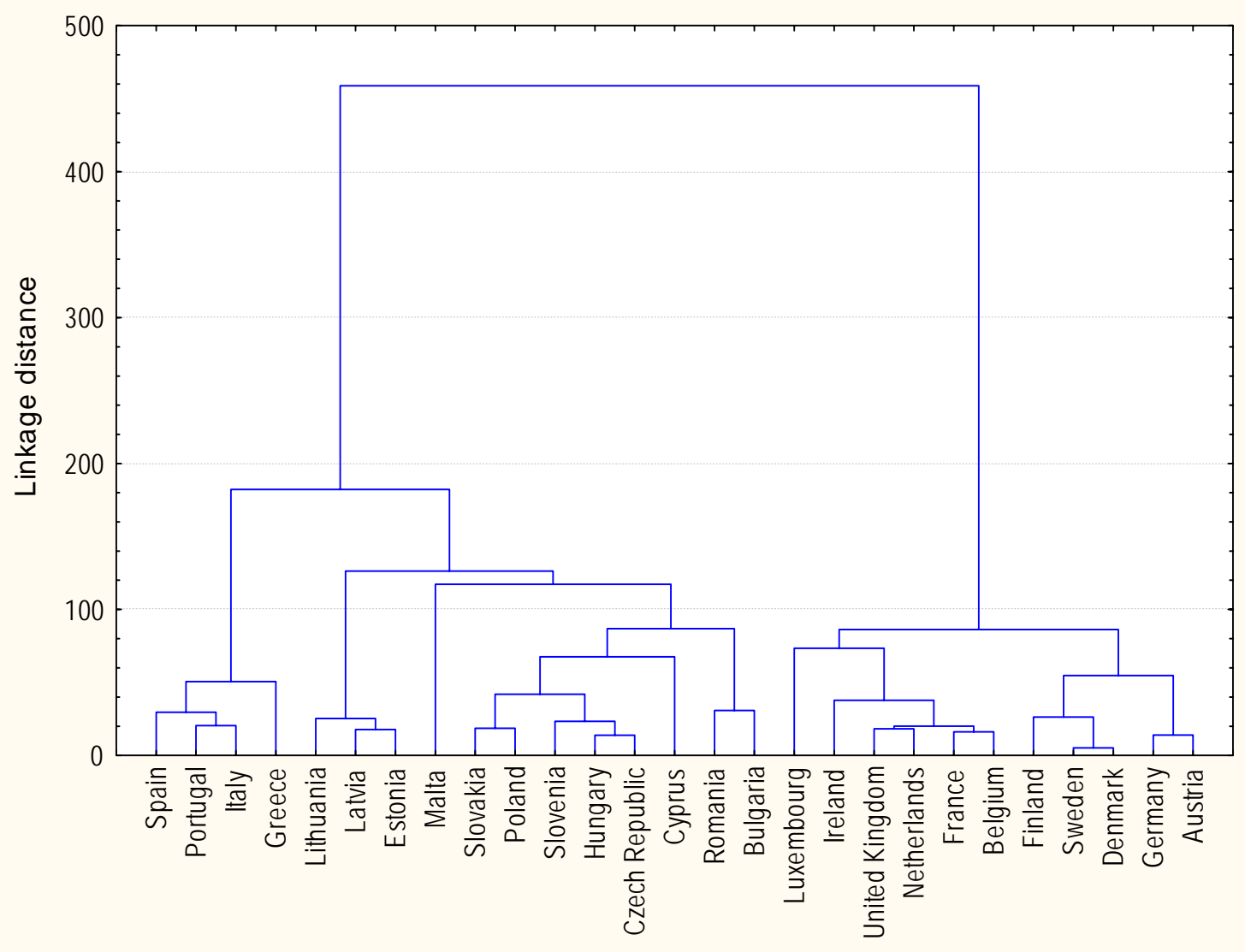

Figure 2. Classification of the EU countries according to TMD In 2013: Ward's Method, Euclides Distance. Source: Own work based on the Eurostat, World Bank, Euromonitor Databases.

Classification of countries in 2013 allows choosing five groups of countries. The number of groups decreased compared with 2000, because in 2013 the groups 3 and 4 merged. In addition, a few transfers took place among other groups. The group of countries, which in 2000 included Poland, Slovakia, Hungary, Slovenia, and the Czech Republic has been extended by three countries: Cyprus, Romania, and Bulgaria. In case of Cyprus, which in 2000 formed a group with Malta, since 2005 one can observe a decline in the value of synthetic measure. In case of Bulgaria and Romania the index increased, which allowed these countries to join the group of countries at a higher level of social development. Countries like Spain, Greece, Italy, and Portugal continue to form a single group throughout the entire period, although in the group of those countries in 2000 was still Austria. A measure of social development for this particular country, however, shows that there has been a very dynamic social development which resulted in shift of this state to the group of countries at a higher level of social development. To sum up, the classification shows a clear division of the EU into countries "old 15" and countries "newly adopted". Within these two groups, there is also a diversification. Among the "old 15", there is a division between the countries of Southern Europe (Spain, Greece, Italy, and Portugal) and the countries of Western Europe and Scandinavia. Among the "new member states", there is a division between the Baltic countries and other countries that joined the EU in 2004. case of Cyprus, which in 2000 formed a group with Malta, since 2005 one can observe a decline in the value of synthetic measure. In case of Bulgaria 
and Romania the index increased, which allowed these countries to join the group of countries at a higher level of social development. Countries like Spain, Greece, Italy, and Portugal continue to form a single group throughout the entire period, although in the group of those countries in 2000 was still Austria. A measure of social development for this particular country, however, shows that there has been a very dynamic social development which resulted in shift of this state to the group of countries at a higher level of social development. To sum up, the classification shows a clear division of the EU into countries "old 15" and countries "newly adopted". Within these two groups, there is also a diversification. Among the "old 15", there is a division between the countries of Southern Europe (Spain, Greece, Italy, and Portugal) and the countries of Western Europe and Scandinavia. Among the "new member states", there is a division between the Baltic countries and other countries that joined the EU in 2004.

In order to observe the relationship among different groups, as well as trends in each group, one averaged the value of synthetic measure at the level of indicated groups, assuming that they represent a homogenous area within the group. The results are presented in Figure 3.

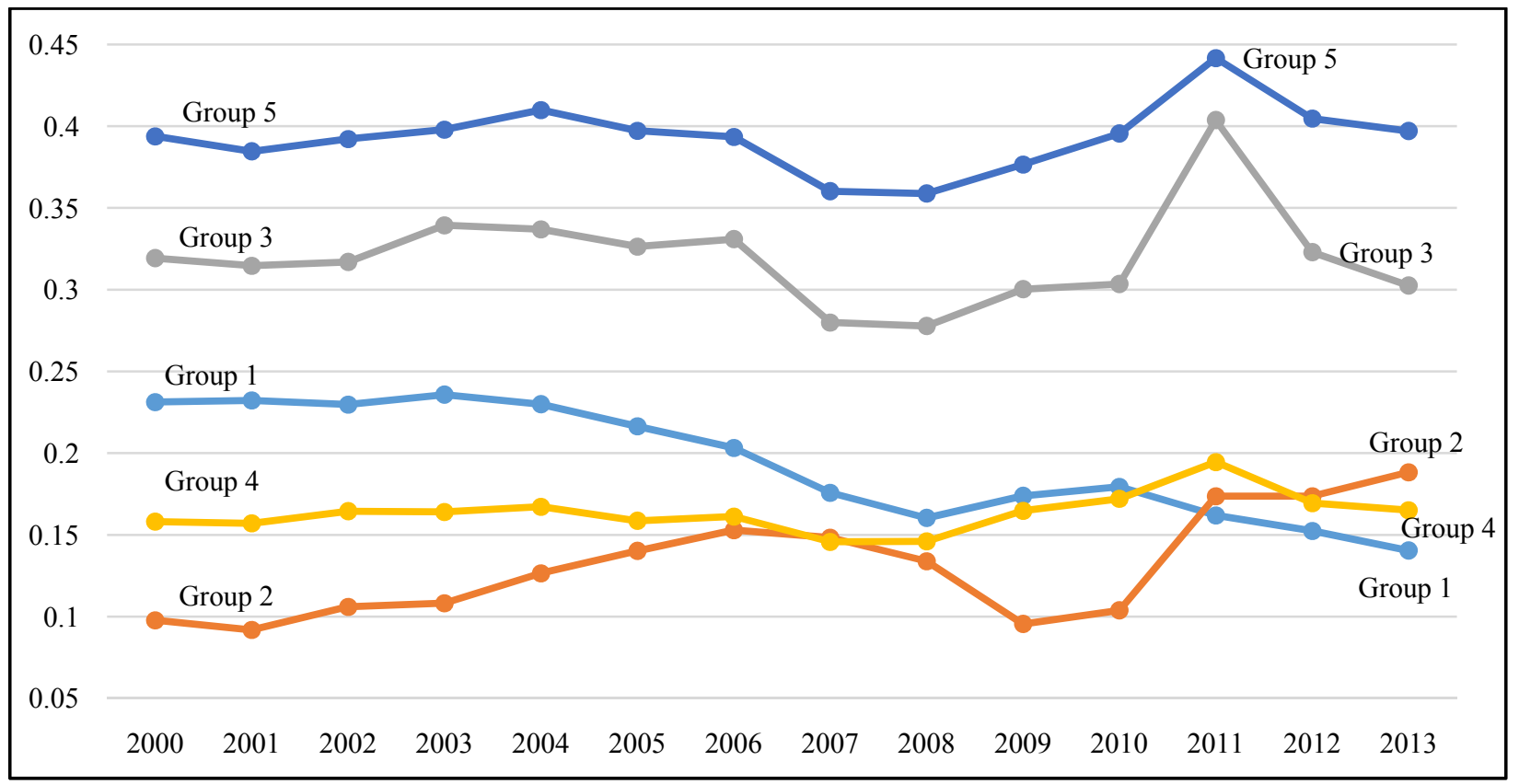

Figure 3. Average mean of taxonomic measure of development for the groups of EU countries in years 2000-2013: Grouping on the basis of the classification in year 2013. Source: Own work based on the Eurostat, World Bank, Euromonitor Databases.

The group, which acquired the highest value of synthetic measure of social development during the entire analysed period is the group 5, which includes countries, such as Luxembourg, Ireland, United Kingdom, Netherlands, France, Belgium, Finland, Sweden, Denmark, Germany, and Austria. The highest level of social development was recorded in Western Europe and Scandinavia. The next country that has a relatively high level of social development is Malta, which in 2013 established a one-piece group No. 3. By 2010, the third most developed group in terms of synthetic measure of development was the group 1, which includes Spain, Portugal, Italy, and Greece. However, after the indicated period, with each year, there is a deterioration of social conditions within this group. It is the only group, which recorded decrease in the level of social development over the years studied. The lowest value of the human development index reached the group 2 : 
Latvia, Lithuania, and Estonia. This group has been hit by the economic crisis, the effects of which are visible especially in the years 2008-2010. However, after this period, there is a very dynamic increase in the level of social development in the group 2.

The analysis of synthetic measure is more constructive if the calculated index is presented in form of the box and whisker plot, which allows assessing the level of social development for the whole EU and trends within the analysed period. On this basis, it is possible to assess social convergence of the European Union countries.

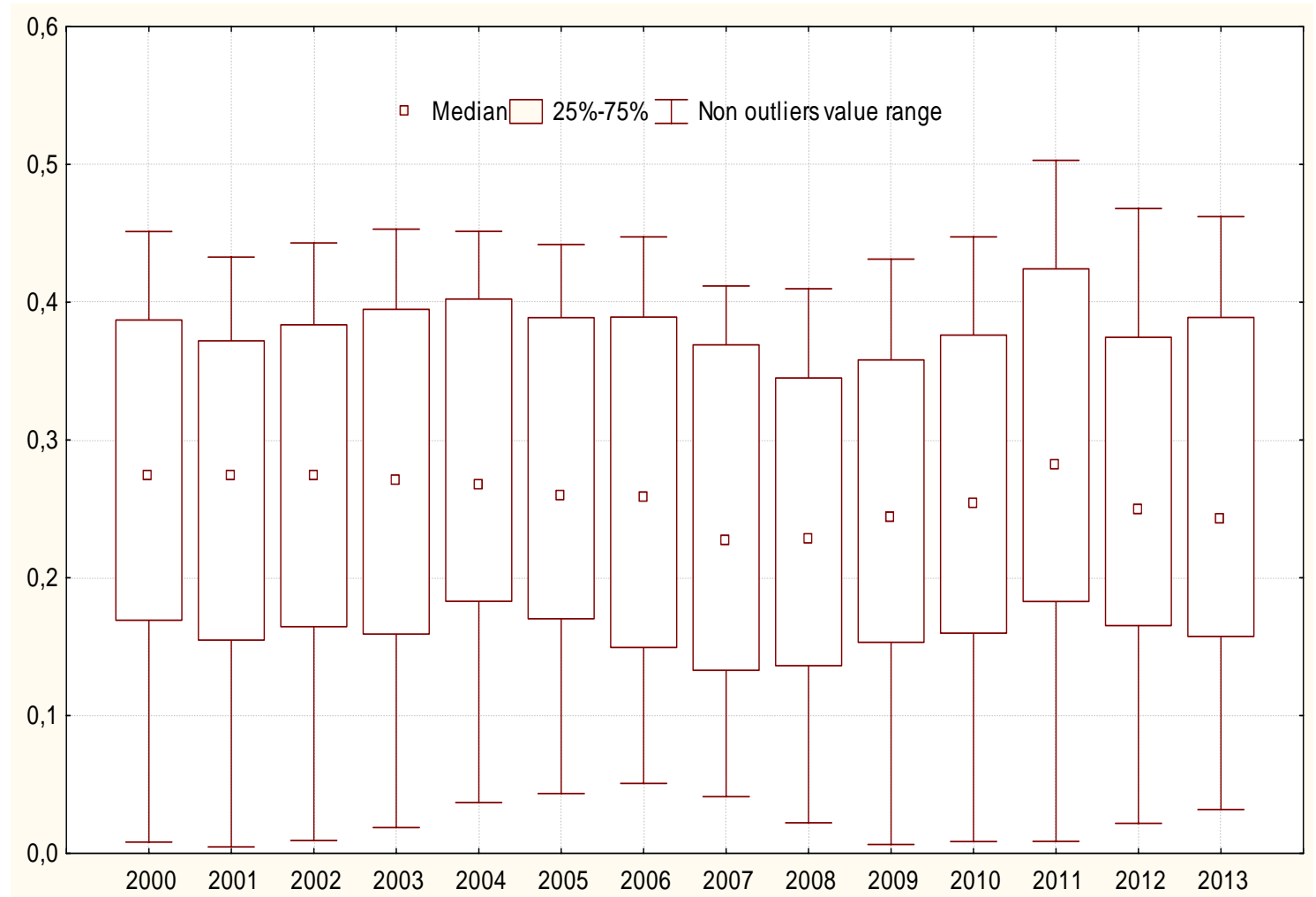

Figure 4. Box and whisker plot of taxonomic measure of development for the EU countries in years 2000-2013. Source: Own work based on the Eurostat, World Bank, Euromonitor Databases.

Figure 4 shows the large discrepancy in terms of social development in the European Union. In the first year, the analysis shows very large gap between the maximum and minimum values of synthetic measure which indicates the large disparities between the richest and the poorest countries in the EU. In the subsequent years until 2007, the value of the gap decreases, which should be regarded as a process of reducing the disparities between countries. In the first three years of the analysis, the minimum values remain at the similar low level, the effect of reducing the disparities was followed by impoverishment of the richer countries. In subsequent years, one can observe fairly dynamic growth of the synthetic measure in countries at the lowest level of development, a similar situation, but with less dynamics, occurs among the richest countries. This reflects the positive growth trends across the Union. Since 2008, however, there is the opposite trend intensifying the diversification of the EU area. It is undoubtedly linked to the economic crisis of that period. Therefore, it should be noted that the economic crisis of 2008/2009 had a very negative impact on the process of social convergence in the European Union. The escalation of negative trends took place in 2011, where there 
is the greatest gap between the most developed and the least developed countries in the Union in terms of social issues. In the following years of analysis, i.e., 2012 and 2013, there is a closer relationship among the countries in terms of social development, which is followed by catching up the richer countries by the poorer ones. The relatively long stretch between the lower whisker and the lower edge of the box indicates that a large discrepancy in terms of development primarily occurs in countries at a lower level of development. This applies to groups of $25 \%$ of countries included in the analysis. This trend continues throughout the period, the standardization of development is evident within the period 2006-2007. In turn, a quarter of EU countries, which are deemed as the richest ones are classified as a homogeneous area where differences are very small. Distribution of synthetic measure is unbalanced, the left-sided asymmetry is highlighted, which means that more countries have a higher value of synthetic measure than the average value. After 2004, the intensity of asymmetry decreases, but it still has a character of negative asymmetry. In the following years, especially during the period of 2006-2007, the distribution can be regarded as moderately symmetrical. This trend was caused by the EU enlargement in 2004 and 2007 which concerned poorer countries. This means that in the EU, the participation of countries, which are less developed, increased, which is also confirmed by the decreasing value of the median. Due to the crisis in the next few years, the asymmetry of distribution increases. To sum up, it can be stated that by the year 2006/2007, the process of convergence in the Union took place primarily due to the development of poorer countries. This process undeniably has been detained by the economic crisis, which has caused even greater differentiation in terms of development of individual countries than in the period before the crisis.

\section{Conclusions}

The analysis of convergence of the European Union is indeed the subject identified in the literature, but the fundamental weakness of previous studies, however, is only bringing convergence to the level of income and consequently its analysis based solely on GDP per capita. This approach seems to be insufficient due to the fact that this indicator does not reflect the actual changes in the level of social development. The multidimensional approach and analysis of social convergence seems to be reasonable. An excellent method of research in this area is the design of synthetic measure by aggregating diagnostic variables that define social development. This approach allows evaluating the level of social development of the European Union countries, as well as answering the question concerning social convergence.

Based on the analysis of synthetic measure of development, it should be noted that the area of the EU is very diversified in terms of social development. Five groups of countries that are similar to each other due to the level of social development can be indicated, although the differences between the groups are quite significant. There is a significant dividing line between the old and new members of the European Union. The leaders of countries in terms of level of social development are Luxembourg, Ireland, United Kingdom, Netherland, France, Belgium, Finland, Sweden, Denmark, Germany, and Austria. The lowest values of synthetic measure concern countries which joined the EU after 2004, including in particular the Baltic countries: Lithuania, Latvia, and Estonia. But it should be noted that the position of these countries has improved over the last three years of analysis. Very negative trends are visible in the group of countries, which includes: Spain, Portugal, Italy, and Greece. At the beginning of the analysed period, these countries occupied a relatively strong position against the EU countries, they preponderated by far the countries of Central-Eastern Europe in terms of level of social development. However, since 2004 their position steadily deteriorated. Since 2011 the level of social development of this 
group of countries is the lowest in the entire EU. The analysis of the box and whisker plot leads to the conclusion that the process of convergence occurred until 2007. Then as a result of the economic crisis, this process has stopped and even a divergence is visible. The period of 2008-2011 reveals the greatest disparity of development among the EU countries. In the last two years, a gradual re-unification of the EU area could be noticed.

\section{References}

Alexe, I. (2012). How does economic crisis change the landscape of real convergence for central and Eastern Europe? Retrieved from http://www.rjfp.ro/issues/Volume3_Issue1_Alexe.pdf

Bielecka, A. (2011). Statystyka dla menedżerów. Warszawa: PWN.

Cuestas, J. C., Monfort, M., \& Ordonez, J. (2012). Real convergence in Europe: A cluster analysis. Retrieved from http://eprints.whiterose.ac.uk/74527/1/serps_2012023.pdf

Dvorokova, K. (2014). Sigma versus beta-Convergence in EU28: Do they lead to different results? Retrieved from http://www.wseas.us/e-library/conferences/2014/Tenerife/ECONMATH/ECONMATH-13.pdf

European Commission. (2007). Fourth report on economic and social cohesion. Retrieved from http://ec.europa.eu/regional_policy/sources/docoffic/official/repor_en.htm

European Commission. (2010). Fifth report on economic, social and territorial cohesion. Retrieved from http://ec.europa.eu/regional_policy/sources/docoffic/official/repor_en.htm

Glodowska, A. (2012). Znaczenie konwergencji $w$ aktualnej $i$ przyszłej polityce strukturalnej UE. Retrieved from https://www.ur.edu.pl/file/16780/13.pdf

Hellwig, Z. (1967). Procedure of evaluating high manpower data and typology of countries by mean of taxonomic methods. Paris: UNESCO.

Hellwig, Z. (1968). Zastosowanie metody taksonomicznej do typologicznego podziału krajów ze względu na poziom rozwoju oraz zasoby i strukturę wykwalifikowanych kadr. Przeglad Statystyczny, 4, 307-326.

Kaitila, V. (2004). Convergence of real GDP per capita in the EU15. How do the accession countries fit in? Retrieved from http://aei.pitt.edu/1843/1/ENEPRI_WP25.pdf

Matkowski, Z., \& Próchniak, M. (2006). Zbieżność rozwoju gospodarczego krajów Europy Środkowo-Wschodniej do Unii Europejskiej. In M. Stawicka (Ed.), Integracja a konkurencyjność przedsiębiorstw w UE (pp. 73-88). Warsaw: Szkoła Wyższa im. B. Jańskiego.

Stiglitz, J. E., Sen, A., \& Fitoussi, J. P. (2009). Report by the Commission on the Measurement of Economic Performance and Social Progress. Retrieved from http:/www.stiglitz-sen-fitoussi.fr/documents/rapport_anglais.pdf

European Economic Community. (1957). Treaty of Rome. Retrieved from http://www.eurotreaties.com/rometreaty.pdf

Varblane, U., \& Vahter, P. (2005). An analysis of the economic convergence process in the transition countries. Retrieved from http://papers.ssrn.com/sol3/papers.cfm?abstract_id=757204 